\title{
PUBLIC FUNDING OF CIVIL SOCIETY ORGANIZATIONS IN LATIN AMERICA: HOW DO WE EVALUATE PROFITABILITY?
}

\author{
Stephen John Beaumont ${ }^{1}$
}

\begin{abstract}
For Latin American states, it is common practice to channel public funds to Civil Society Organizations (CSOs) to meet various social needs. However, the impact of this investment is not well understood. There is a need for a deeper knowledge of the issues, such as the components that are being financed and how CSOs use the resources. Also, a better understanding of the impact on the individual beneficiaries of the CSOs is necessary. These issues need resolving to move towards optimizing the use of State resources for the common benefit of society. The main hypothesis of this study is that, although the State generally invests a large amount of funding into CSOs, this funding is inefficiently distributed. A more efficient State funding for CSOs, in terms of positive social impact, would make these organizations more socially profitable.
\end{abstract}

JEL Classification Numbers: H25, M89, I01, DOI: http://dx.doi.org/10.12955/cbup.v4.786

Keywords: civil society organizations, state funding, social profitability.

\section{Introduction}

For many Civil Society Organizations (CSOs), also called Non Profit Organizations (NPOs), a percentage of its annual budget derives from funds of the State (often referred to as grants). For some organizations that tend to highly vulnerable, these contributions constitute their main source of income. Moreover, for various Latin American states (with the exception of Cuba, whose legislation does not contemplate the existence of CSOs), it is a common practice to channel public funds into these organizations to meet various social needs. This is not new, rather it has been implemented for many years and this interaction is fairly uniform among the countries of the region and between their respective provinces, states, departments, and regions.

Large variations are detected in how funding for CSOs is provided by the State. Further analysis of this is needed beyond the amounts provided by the State or the percentages of the budget of the respective CSO recipients, to assess the effectiveness or efficiency of these financing models. A deeper knowledge of such issues regarding the financing of CSOs and how CSOs use the resources is needed. Also, a better understanding of the impact on the individual beneficiaries of the CSOs is necessary. These issues need resolving to move towards optimizing the use of State resources for the common benefit of society. Understanding the best way for the State to strengthen CSOs will help improve their performance towards this common benefit. Overall, it is usual for organizations that continually receive State funds to be on the verge of financial bankruptcy. In these cases, options could include increasing budgetary allocations or alternatively, strengthening the institution to reach a more efficient financial management.

The aim of this paper is to identify issues and possible solutions relating to the funding of CSOs. The main hypothesis of this study is that, although the State generally invests a large amount of funding into CSOs, this funding is inefficiently distributed. Increasing efficiency of this State funding for CSOs, in terms of positive social impact, will likely increase the socially profitability of these organizations.

\section{Sources of State Finance for CSOs}

The starting point of this research was the work, 'Financing Organizations of Civil Society Organizations (CSOs) by the State in Argentina: What goals should be pursued?' by Beaumont (2014).

The objective of this work was to survey the areas of investment by the State in providing funding for CSOs, and to better judge the effectiveness of the expenditure. Given that the State, at different levels, regularly invests significant amounts of money in a huge number of CSOs, it would be important to

\footnotetext{
${ }^{1}$ Stephen John Beaumont, Centro de Tecnología para el Desarrollo (CENTED), Buenos Aires, Argentina, info@cented.org.ar
} 
analyze the effect that this has on the organizations themselves and their beneficiaries. It will not have the same impact, for example, if the funding is used for institutional development of the CSO or that the organization is simply used as an intermediary to reach the final beneficiary. While the logic of government social programs is to channel public resources to individual final beneficiaries, when this is implemented through CSOs, it is reasonable to analyze the percentage of these resources reaching the beneficiary and that which is consumed in operating or management costs. Effectively analyzing these interactions between the State and CSOs will provide an understanding or at least an estimate of the 'social profitability' of the current State's investments, and therefore, the potential to optimize the allocation of these resources in the future. The research methodology consisted of a survey of members from various CSOs and government officials, using a questionnaire with open and closed questions. Some of the results for the questions posed, included:

- What sort of State resources has been received in the last 2 years? (You could indicate more than one). In order of importance, participants elected: grants (money), donations of goods or products or both for specific purposes, human resources (volunteers), property lease, technical support, debt forgiveness (mainly municipal taxes) and training (direct or scholarships or both).

- In the case of grants, were they freely available or should they be used within the framework of a particular program? 93\% stated that they were to be used in a given program: whereas $7 \%$ had free availability to use them.

- In your experience, State funding is continuous or discontinuous? For $14 \%$ of the people surveyed it was continuous, but for the remaining $86 \%$, it was the opposite.

- Do you think the State can better target funding for other needs of CSOs? Whereas $97 \%$ answered yes, only $3 \%$ answered no.

Moreover, the study of 2015 (Beaumont, 2015), surveyed further issues concerning training within CSOs, such as:

- Do you think that you possess all the skills required for the tasks carried out within your organization? Of the respondents, $47 \%$ answered that they did, and $53 \%$ said that they did not.

- Do you believe that there is an adequate supply of training for CSOs? While $8 \%$ responded affirmatively, $63 \%$ thought the opposite. Additionally, 29\% thought that there was, but it was too expensive.

- Did you participate in any training (in the last 2 years) that specifically refers to CSOs? While $18 \%$ affirmed that they did, an overwhelming $82 \%$ did not.

- If you did not participate in any training (in the last 2 years) that specifically refers to CSOs. Why? Of the respondents, $51 \%$ stated that they lacked resources, $28 \%$ stated that they lacked time, and $21 \%$ found no interesting offer.

- What areas do you think should be strengthened within your organization, both through training and technical assistance? (You can check more than one). In order of importance, participants elected: fundraising, tax issues or accounting, general topics of management, institutional communication, legal issues, human resources, and marketing.

Some of the conclusions reached in the study (Beaumont, 2015), included:

- The State funding is rarely directed to areas of technical assistance or training (direct and / or scholarships).

- However, there is an unmet need for specific training for CSOs, especially for the members of Committees or Boards of Directors.

- In general, the perception is that there is an inadequate supply of training for CSOs. However, there are an overwhelming majority of members of these organizations who are in need for specialized training.

- Therefore, promoting this training could positively influence the overall performance of these organizations, in terms of their impact on the common good for the communities in which each one works.

- Finally, the State could optimize resources by enhancing the institutional strengthening of Civil Society Organizations. 
Overall, future research into this area could analyze the efficiency of social investments between the State and CSOs. The aim of this would be to analyze the effectiveness of State investment in providing funding for CSOs, to better understand the impact of the resources consumed on the final beneficiaries. How to evaluate State investment in CSOs requires further understanding.

\section{Social Profitability}

Beyond the knowledge that the State regularly invests significant amounts of money in a huge number of CSOs, it is essential to analyze the effectiveness of this on each organization, its beneficiaries, and society as a whole, giving priority to the efficient allocation of State resources. Although it seems that social investment is beyond traditional economic analysis, at some point analyze or at least an estimate of the "social profitability" of State investment is possibly needed to optimize the limited allocation of resources.

In terms of profitability, analyzing social benefits is supported in that CSOs are having to cope with limited resources, and any organization should prioritize the most efficient allocation thereof and from that premise, establish mechanisms that allow them to estimate the profit maximization. As part of a research project on agricultural development at Stanford University, Monke and Pearson (1989) defined profitability or social gain ("Social Profit"), as the "measure of efficiency or comparative advantage" of the investment.

Such a case cannot be analyzed with classic financial indicators, for example, in assessing the profitability of a private sector project in terms of Return on Investment (ROI), Internal Rate of Return (IRR), or Net Present Value (NPV). Unlike a commercial project, there is no financial formula to analyze the social benefits of a project. The evaluation of a social project should compare costs and benefits that an investment may have in a community and as a whole. However, in addition to the direct benefits, one must take into account indirect, intangible effects (such as welfare in the community) and the (positive and negative) externalities generated by the project. This is perhaps where the greatest challenge lies, as Grinols and Mustard (2001) mentioned in their work, 'Business Profitability versus Social Profitability: Evaluating Industries with Externalities. The Case of Casinos', that "Failure to account for all of the components of social profitability is perhaps the most common mistake" (p. 147).

This is not the only problem; Hagan $(2009$, p. 2$)$ stated that: "the concept of social profits implies that the project will generate a positive social surplus if, and only if, it yields a larger contribution to the national value added value than the input of resources would have generated in the best alternative use. Essentially, the valuation problem boils down to whether market prices can be used for assessing the social profitability."

Beyond the positive social impact generated by any project, both from the State and the private sector, special attention is placed on the cost-benefit of that undertaken by CSOs that receive public funding. For example, Philipson and Lakdawalla (2001) in 'Medical Care Output and Productivity in the Nonprofit Sector,' wrote of "a growing concern about the productivity, or so called cost-effectiveness, of the health care industry", as part of the nonprofit sector.

\section{Conclusion}

Today, the dominant paradigm of State investment in CSOs is the 'grant culture'. However, this paradigm is not socially profitable in terms of the percentage of public funds that reach the final beneficiaries, and a great many CSOs do not break the "vicious cycle" involved with Statedependence. An alternative would look to the funding models of many 'successful' CSOs that show a minimal percentage (if any) of State funding.

Although, the State invests in CSOs, it appears to invest inappropriately. Paraphrasing an ancient proverb, it could be considered that "it gives away fish instead of teaching people how to fish".

In terms of changing the paradigm, investing in institutions by strengthening through training could improve the CSOs performance and their social impact.

This would have a double benefit for the State. First, it would provide a network of efficient CSOs to provide public benefits and meet various social needs. This, over time, would save funds with the provision of public benefits through CSOs reducing State spending. Second, funding is also saved by not having to eternally subsidize inefficient organizations. 


\section{References}

Beaumont, S. (2014). "Financiamiento de las organizaciones de la sociedad civil por parte del Estado en la Argentina: ¿Qué objetivos se deberían perseguir?" XIX Congreso Internacional del CLAD ["Funding of civil society organizations by the State in Argentina : What goals should be pursued?" XIX International Congress of CLAD]. Quito, Ecuador.

Beaumont, S. (2015). "Rentabilidad social: ¿cómo optimizar la inversión pública a través de las organizaciones de la sociedad civil?” XX Congreso Internacional del CLAD sobre la Reforma del Estado y de la Administración Pública. Lima, Perú ["Social profitability : how to optimize public investment through civil society organizations?" XX International Congress of CLAD on State Reform and Public Administration . Lima Peru].

Grinols, E. \& Mustard, D. (2001). "Business Profitability versus Social Profitability: Evaluating Industries with Externalities, The Case of Casinos." Managerial and Decision Economics 22: 143-162.

Hagen, K. P. (2009). "Project profitability from society's point of view." In T.M. Williams, K. Samset and K.J. Sunnevag (eds.). "Making Essential Choices with Scant Information: Front-end Decision Making in Major Projects." Palgrave: Basingstoke, UK. Available at http://www.ntnu.edu/concept/articles-and-papers

Monke, E. A. \& Pearson, S. R. (1989). "The policy analysis matrix for agricultural development.” Outreach Program, Food Research Institute, Stanford University. Available at http://web.stanford.edu/group/FRI/indonesia/documents/pambook/pambook.pdf

Philipson, T. \& Lakdawalla, D. (2001). "Medical Care Output and Productivity in the Nonprofit Sector," en David Cutler and Ernst Berndt, "Medical Care Output and Productivity." University of Chicago Press. Available at http://www.nber.org/chapters/c7627 